\title{
CONVENTIONALISM IN CONSTITUTIONAL INTERPRETATION AND THE PLACE OF ADMINISTRATIVE AGENCIES
}

\author{
Peter M. Shane*
}

On a single day in 1935, the Supreme Court announced three anti-New Deal decisions that helped provoke Franklin Roosevelt's attack on the Court's structure and membership. ${ }^{1}$ The better known of the three are Humphrey's Executor v. United States, ${ }^{2}$ and A.L.A. Schechter Poultry Corp. v. United States. ${ }^{3}$ Humphrey's Executor explained in categorical and seemingly simple-minded terms why the President could not discharge all regulatory commissioners at will. ${ }^{4}$ Schechter is the last vigorous stand of the federal nondelegation doctrine. ${ }^{5}$ It also represents one of the Court's last attempts to read Congress' commerce powers narrowly on the understanding that federalism places judicially enforceable limits on congressional regulatory power. ${ }^{6}$

* Professor of Law, University of Iowa. A.B. (1974), Harvard; J.D. (1977), Yale. I would like to express my appreciation to Martha Chamallas, Steve Burton and Jeff Powell for their thoughtful comments on this essay. This essay is dedicated to the memory of Professor Robert Cover of Yale, a brilliant and humane practitioner of the interpretive art. All his former students will miss his personal encouragement and inspiration.

1. On May 27, 1935, the Supreme Court announced three anti-New Deal decisions: Humphrey's Ex'r v. United States, 295 U.S. 602 (1935), A.L.A. Schechter Poultry Corp. v. United States, 295 U.S. 495 (1935), and Louisville Joint Stock Land Bank v. Radford, 295 U.S. 555 (1935).

2. 295 U.S. 602 (1935).

3. 295 U.S. 495 (1935).

4. Humphrey's Ex'r v. United States, 295 U.S. 602, $631-32$ (1935). The Court held that, when Congress provides for the appointment of officers whose functions are non-executive in nature, and restricts the grounds on which the officers may be discharged, the President has no constitutional power to remove them for reasons other than those specified by Congress. Id.

5. See A.L.A. Schechter Poultry Corp. v. United States, 295 U.S. 495, 529 (1935) (noting that Congress is not constitutionally permitted to abdicate or transfer its vested legislative functions).

6. See id. at 550-51. In Schechter, the Court struck certain provisions of a "Live Poultry Code" (Code) which the President had approved under section three of the National Industrial Recovery Act. Id. The Court held that Congress may not delegate "virtually unfettered" authority to the President to make laws affecting trade and industry. Id. at 542. Moreover, the 
The structural implications of Schechter have fared badly. The Court has quietly, but conspicuously, buried Schechter's stance on nondelegation. ${ }^{7}$ In Garcia v. San Antonio Metropolitan Transit Author$i t y,{ }^{8}$ the Court interred-or, more accurately, reinterred ${ }^{9}$-its creative efforts on behalf of federalism. Now, the categorical version of the separation of powers proffered by Humphrey's Executor may be gasping its last. ${ }^{10}$

In each of these developments, I see what may be a common theme. If present, it would be an important theme, but it is so often stated implausibly that I utter it here only as a hypothesis and in anticipation of considerable elaboration. In both developments, we may be returning to a reading of the structural and operational provisions of the Constitution that seems most obviously to reflect the conventional meaning of the Constitution's language and its most conventionally understood implications. 11 Further, because these conventional meanings are so commonly interpreted, we are finding that the Constitution, in at least some of its structural and operational provisions, speaks most sensibly when it is treated as "speaking plainly," even in the modern administrative state. ${ }^{12}$

This hypothesis occurred to me for two reasons. First, at least some of the Court's excursions into administrative theory independent of the constitutional text seem question-begging and confusing.

Court stated that the Code provisions to fix hours and wages of defendants' employees in their intrastate business was a constitutionally invalid exercise of federal power. Id. at $\mathbf{5 5 0 .}$ See also Louisville Joint Stock Land Bank v. Radford, 295 U.S. 555, $601-02$ (1985) (invalidating Frazier-Lemke Bankruptcy Act which provided federal farm mortgage relief).

7. American Textile Mfrs. Inst. v. Donovan, 452 U.S. 490, 543 (1981) (Rehnquist, J., dissenting) (criticizing congressional delegation of "hard policy choices" to Executive Branch in enacting occupational safety and health standards). But $c f$. National Cable Television Ass'n, Inc. v. United States, 415 U.S. 336, 342 (1974) (reading statute narrowly to avoid difficult issue of constitutional delegability).

8. 429 U.S. 528 (1985) (overruling National League of Cities v. Usery, 426 U.S. 838 (1976) and holding that tenth amendment does not immunize state transit authority from minimum wage and overtime requirements of Fair Labor Standards Act, enacted by Congress under commerce clause).

9. See United States v. Darby, 312 U.S. 100, 124-25 (1941) (holding Congress had authority under commerce clause to regulate working conditions where manufactured goods are shipped in interstate commerce).

10. See Buckley v. Valeo, 424 U.S. 1, 135-36 (1976) (disregarding Humphrey's Ex'r as inapposite to questions of presidential appointments).

11. For a discussion of various definitions of "conventionalism," see infra note 23.

12. This is not to say that (a) all structural and operational provisions of the Constitution are susceptible to plain reading, or (b) no power-limiting provision of the Constitution is so susceptible. The analysis that follows might apply, for example, more readily to the warrant clause of the fourth amendment, U.S. Const. amend. IV, than to the question whether the President may abrogate a treaty without the consent of either House of Congress. See Goldwater v. Carter, 444 U.S. 996 (1979) (discussing congressional opposition to President's unilateral termination of defense treaty with Republic of China), vacating 617 F.2d 697 (D.C. Cir. 1979). 
For unhelpful dicta, Humphrey's Executor is the worst example. Second, I have never found much in the constitutional status of the agencies that is truly uneasy. What is chiefly uneasy is the agencies' political status, and that is because, on my reading, the Constitution plainly seems to leave the shaping of administrative agencies essentially to the political branches, with Congress playing the predominant, but not exclusive oversight role.

The principal papers reinforce my conviction that the action here is nearly all political ${ }^{13}$ because they show little disagreement on any legal question. Indeed, although Professor Bruff finds presidential regulatory oversight more agreeable on policy grounds than Professor McGarity, ${ }^{14}$ he does not dispute his colleague's urging that Congress play a more vigorous role in overseeing the world of administrative regulation. ${ }^{15}$ Certainly there is nothing in Professor Bruff's remarks suggesting that any of Professor McGarity's tendered reforms would be unconstitutional.

Although it follows that, like Professor Bruff, I view the truly important administrative law debates as political, my essay focuses on the constitutional rather than the policy side of things to help counterbalance a problem in the world of scholarly (and perhaps of even more popularly digested) constitutional law. The unabating literature on constitutional theory and metatheory ${ }^{16}$ often ignores separation of powers questions as terrain for interpretation. ${ }^{17}$ The texts that animate most debates over constitutional interpretation are such words as "privileges and immunities,"18 "equal protection of the laws," 19 and "due process." 20 Fourteenth amendment jurispru-

13. Professor Bruff has gone so far in revising his remarks as to argue that "no more detailed anatomy is necessary or desirable at the constitutional level." Bruff, On the Constitutional Stalus of the Administrative Agencies, 36 AM. U.L. REv. 491, 491 (1987) (emphasis added) (footnote omitted).

14. See McGarity, Presidential Control of Regulatory Agency Rulemaking, 36 Am. U.L. REv. 443, $463-89$ (1987).

15. Compare id. at 457 (stating that President is unaccountable for agency decisions and that agencies can usually manipulate analysis of existing data to fit presidentially required outcome) with Bruff, supra note 18, at 509 (stating that President cannot make every decision and that President's responsibility is logically, therefore, one of oversight).

16. I refer here to literature concerning the general enterprise of constitutional interpretation, not to the voluminous literature actually interpreting the first three articles of the Constitution.

17. For recent notable exceptions to this statement, see Carter, Constitutional Adjudication and the Indelerminale Text: A Preliminary Defense of an Imperfect Muddle, 94 YALE L.J. 821, 853-87 (1985) (differentiating interpretation of clearly determinate constitutional clauses from less clearly determinate clauses protecting individual rights) and Schauer, Easy Cases, 58 S. CAL. L. REv. 399 (1985) (discussing textual interpretation of structural provisions in Constitution as "easy cases").

18. U.S. Const. amend. XIV, §1.

19. Id.

20. Id. 
dence, however, may require interpretive strategies that are less obviously necessary to construing the Constitution's opening articles. ${ }^{21}$

To see this point, it is helpful to reflect first on the chief reasons why theory, and normative theory especially, plays a conspicuous part in the interpretation of certain provisions of the Constitutioneven where the relevant normative theory is highly controversial. I believe that these reasons do not pertain as strongly to the interpretation of much of articles I and II of the Constitution. ${ }^{22}$ Admittedly, interpreting these articles requires normative theory also. But, we can get surprisingly far in the interpretive enterprise by relying on value premises that are uncontroversial in the sense that, although they are debatable, they are not at issue for our particular society. To test this hypothesis, I will attempt to elaborate and apply a conventionalist method $^{23}$ to interpreting articles I and II of the Constitution as they relate to a series of questions regarding administrative agencies. I will discuss the plausibility of the method and also its inability to answer all constitutional questions regarding administrative agencies. If $I$ am right that such an interpretive strategy is possible for at least a significant minority of important questions, I would like to consider the implications of a Constitution that seems, in its different aspects, to evoke different interpretive strategies, and of the availability of conventionalist "plain reading" as a helpful route to answering some, though by no means all, questions of administrative structure and design.

21. Carter, supra note 17 , at 852 (contrasting presentment clause embodying "concrete conception of the way a particular government process is at work" with due process clause stating "very vague and very general value preference").

22. See U.S. ConST. art. I (legislative power); id. art. II (executive power).

23. It is only with trepidation that I borrow "conventionalism" or any other brief label to capture the essence of the argument that follows. See Schauer, supra note 17, at 438 (noting that "apart from a general objection to 'ismism,' I find such characterizations either simply inaccurate, ..., or merely misleading ..."). Aside from the customary capacity of labels to oversimplify, my particular label suffers from the variability with which it is used in scholarship. For example, Professor Dworkin describes "conventionalism" in his most recent work as a conception of law (that he disapproves and which I do not share) that limits law "to what has been endorsed by legal conventions." R. Dworkin, LAw's EMPIRE 123 (1986). What I have in mind is, instead, an interpretation that emphasizes practice and context, and looks to community agreement as a referent for the accuracy of interpretation. See generally Fiss, Conventionalism, 58 S. CAL. L. REv. 177 (1985) (defining conventionalism as viewpoint that emphasizes practice and context); S. Burton, An InTroduction To LAw AND Legal Reasoning 9498 (1985).

Because I believe that the structural and operational phrases relevant to administrative agencies are often so commonly understood by all persons who read the Constitution, my emphasis on practice and context in this area supports, in my view, a "plain reading" approach to the interpretation of these phrases. This is by no means to suggest, however, that a dictionary-oriented approach to textual interpretation is always or even usually consistent with conventionalism. 


\section{Individual Rights ANd the "Pull" of PhIlosophy}

Most governmental decisions that affect us are state and local decisions. The federal constitutional limitations on state and local government emanate predominantly from the fourteenth amendment insofar as it guarantees due process, equal protection, and such fundamental rights as are deemed "incorporated" through those provisions, the privileges and immunities clause, or some combination of such terms. Despite the wealth of scholarly literature to the contrary, ${ }^{24}$ the application of these textual phrases to litigated factual disputes inevitably involves conspicuous resort to controversial moral and political philosophy to give meaning to the rights they create.

First, the key provisions of these and most individual rights guarantees in the Constitution ${ }^{25}$ are manifestly vague and contested. ${ }^{26}$ There is no undisputed cultural identification of what is a "privilege" or an "equal protection," or a "due process" that constrains us in our attempt to impute conventional, much less sensible, meaning to those words. ${ }^{27}$ This is partly because the possible and plausible ordinary meanings of the words (both contemporary and historical) are so multifarious. ${ }^{28}$ There is also no strong evidence that the drafters and ratifiers of those words united around any particularistic definitions that we can regard as authoritative. ${ }^{29}$ Even if

24. See, e.g., Meese, Construing the Constitution, 19 U. CaL. Davis L. Rev. 22 (1985); Bork, Neutral Principles and Some First Amendment Problems, 47 IND. L.J. 1 (1971).

25. As noted above, supra note 12 , I do not mean this statement to apply either exclusively or universally to individual rights provisions. References to the "free exercise" of "religion," U.S. CoNST. amend. I, and "the general Welfare of the United States," id. art. I, § 8, cl. $\mathrm{I}$, are equally vague and contested; references to a "Grand Jury," $i d$. amend. V, and a "Term of four Years," id. art. II, $\S \mathrm{l}$, cl. 1, are not vague and contested.

26. It may be that the lesser intelligibility of these phrases is alone sufficient to explain why straightforward readings of these phrases are less likely than straightforward readings of articles I and II. Cf. Schauer, supra note 17, at 415 (stating that "vague, ambiguous, or simply opaque linguistic formulation" of relevant rule can also create hard case). My guess is, however, that the universally apprehended normative significance of the topics covered by these phrases would precipitate hard cases in their application even if they were linguistically easier.

27. I do not mean to revive any philosophical distinction between physical objects, like "the President," which some people might regard as identifiable without interpretation, and normative concepts, such as due process, which are not. All phenomena require interpretation. Certain phenomena, however, such as "Congress" or a "bill" have been so thoroughly interpreted that there remains no genuine dispute as to their meaning.

28. See generally Goldberg, "Interpretation" of "Due Process of Law"-A Study in Futility, 13 PAC. L.J. 365 (1982) (exploring "due process"); D. RAE, EQualrties (1981) (discussing "equality" in theory and practice); Comment, The Privileges or Immunities Clause of the Fourteenth Amendment: The Original Intent, 79 Nw. U.L. REv. 142, 158-76 (1984) (discussing "privileges or immunities").

29. Cf. Brown v. Board of Educ., 347 U.S. 483, 489 (1954) (determining that arguments made were inconclusive as to fourteenth amendment's intent vis-á-vis racial segregation); P.L. Murphy, The Constitution In Crisis Times $309 \mathrm{n} .98$ (1972) (describing NAACP efforts to research background to fourteenth amendment). 
such historical understandings were available, there is no strong evidence that the drafters and ratifiers intended their language to refer only to those understandings. ${ }^{30}$ If we are going to be consistently intentionalist, we, of course, would have to respect the originators' interpretive intention as well. ${ }^{31}$

But perhaps most importantly, everyone, irrespective of politics, genuinely wants to read the individual rights guarantees, including the fourteenth amendment, against the backdrop of "extraconstitutional" normative theory. There is much discussion, of course, about faithfulness to the language and framers' intentions, but no one, I think, is truly prepared to live with the implications of that approach.

Brief reflection suggests this is likely to be the case even with respect to Attorney General Edwin Meese, who has become for the moment our best known advocate of intentionalism in constitutional interpretation. ${ }^{32}$ In essence, the Attorney General has strenuously urged that courts go no further than the text, history, and structure of the Constitution in giving meaning to constitutionally created rights. ${ }^{33}$ Putting aside all scholarly quibbles about the possibility of stating that position coherently, it is easy to posit a series of cases in which the Attorney General would surely depart from this interpretive position.

The most obvious instance is affirmative action based on race. Whether the Constitution protects white candidates for employment or for other government benefits from decisionmaking criteria that favor minority applicants cannot be determined by its language. ${ }^{34}$ Where language fails, the Attorney General recommends resort to history-and herein lies his problem. The principal originators of the fourteenth amendment were also drafters of legislation

30. See Brest, The Misconceived Quest for the Original Understanding, 60 B.U.L. REv. 204, 216 17 (1980) (asserting that Constitution's originators may have intended to provide more interpretive freedom than is generally recognized); Powell, The Original Understanding of Original Intent, 98 HARv. L. REv. 885 (1985) (discussing meaning of intent in constitutional interpretation).

31. Brest, supra note 30, at 217 (stating that intentionalist interpretation must determine to what degree ratifiers intended to constrain future interpretation of each constitutional provision).

32. Meese, supra note 24 (reprinting address given by Attorney General Meese outlining his theory of intentionalist constitutional interpretation).

33. Id. at $24-26$.

34. It is sometimes said that the words "equal protection" preclude differential decisionmaking by race. See Plessy v. Ferguson, 163 U.S. 537, 559 (1895) (Harlan, J., dissenting) (asserting "[o]ur constitution is color-blind, and neither knows nor tolerates classes among citizens"). That, of course, is not so. If blacks and whites are different in some respect relevant to the benefit being distributed-for example, based on need or on opportunity to develop the customary qualifications-then the words "equal protection" would seem not only to permit differential treatment, but to compel it. 
designed to assist former slaves and their descendants. ${ }^{35}$ It is implausible to assume that those originators understood their constitutional creation might render their statutory creations unlawful. ${ }^{36}$ If history is our guide to the resolution of such cases as Regents of the University of Califormia v. Bakke ${ }^{37}$ or Fullilove v. Klutznick, ${ }^{38}$ the constitutionality of race-conscious affirmative action seems firmly established. Yet, our intentionalist Attorney General is a vigorous proponent of the opposite position. ${ }^{39}$

Similarly, the Attorney General attacks the theory of fundamental rights "incorporation" as resting on a dubious intellectual foundation, thus urging the Court to repudiate its allegiance to textually unspecified fundamental rights deemed binding on the states through the due process clause. ${ }^{40}$ Even if he is correct, however, surely the Slaughter-House Cases, ${ }^{41}$ in which a narrow majority of the Court failed to read fundamental rights guarantees into the privileges and immunities clause of the fourteenth amendment, is at least as dubious on textual, historical, and structural grounds. ${ }^{42}$ The Attorney General, to my knowledge, has never mentioned this point. Likewise, the recognition of corporations as "persons" protected by the fourteenth amendment ${ }^{43}$ is a judicial doctrine that flies conspicuously in the face of the Constitution's language, history, and structure. At the risk of stereotyping the Attorney General's views unfairly, I doubt he would seek the reversal of this doctrine.

Finally, virtually all commentators on equal protection embrace ethnicity as a constitutionally protected classification. Some, like Judge Posner, acknowledge candidly the ahistoricism of such a principle; ${ }^{44}$ others, like Judge Bork, do not mention it. ${ }^{45}$ Nothing in the

35. See Regents of the Univ. of Cal. v. Bakke, 438 U.S. 265, 397 (1978) (Marshall, J., dissenting) (noting that same Congress that passed fourteenth amendment was same Congress that passed "freedmen" legislation).

36. Id.; see Schnapper, Affirmative Action and the Legislative History of the Fourteenth Amendment, 71 VA. L. REv. 753, 754 (1985) (contending that framers could not have intended to prohibit race-conscious legislation because many such programs were enacted concurrently with fourteenth amendment).

37. 438 U.S. 265 (1978) (plurality opinion) (holding that special admissions program was illegal but that race may be one of several facts considered by schools in passing on applicants).

38. 448 U.S. 448 (1980) (holding that set-aside of federal contracts for minority businesses is constitutional).

39. See N.Y. Times, Sept. 18, 1985, at A16, col. 4. Meese believes quotas are inherently discriminatory. Meese stated that the use of quotas to remedy the effects of past discrimination is, in principle, senseless and in practice "a legal . . . and constitutional tragedy." Id.

40. Washington Post, July 10, 1985, at A6, col. 6 .

41. 83 U.S. (16 Wall.) 36 (1873).

42. Id. at 83 (Field, J., dissenting).

43. Santa Clara County v. Southern Pac. R.R. Co., 118 U.S. 394, 409-10 (1886).

44. Posner, The DeFunis Case and the Constitutionality of Preferential Treatment of Racial Minorities, 1974 Sup. CT. REv. 1, $21-22$ (1974). 
language, structure, or history of the Constitution provides a compelling originalist case for regarding invidious discrimination against German or Irish-Americans as being equally within the fourteenth amendment's purview as invidious discrimination against blacks. ${ }^{46}$ Yet, again at the risk of stereotyping the Attorney General's views, I would wager that, for purposes of constitutional law, he commendably equates the two. If so, this particular position would again conflict with his purported interpretive philosophy.

From these examples, I infer that the fourteenth amendment and other individual rights guarantees implicate issues of our moral life so directly that our moral positions irresistably shape our readings of those guarantees. What constrains us in interpretation is our institutional and social life, not plain meaning or particularistic history.

The truth of this observation may result from a sense in which the "facts" of individual rights cases seem more important than the relevant legal "words." Even making such a statement, however, seems to fall into the misleading way in which lawyers frequently speak of interpretation. Lawyers often speak of legal interpretation as if there were distinct worlds "out there" of already understood "fact," and "in here" of ambiguous text. We speak as if the process of interpretation is concerned with simply imputing such meaning to the relevant legal texts as would lead to the right adjudicative result, given the understood facts.

As anthropologist Clifford Geertz, among others, has powerfully asserted, however, the world of facts is as least as complex and in need of interpretation as the world of words. ${ }^{47}$ Under Geertz's theory, when we lawyers set about interpreting a legal text, we are simultaneously testing alternative interpretations of the world of the real. It is doubtful that any linguistic interpretation can satisfy us if it does not help us to imagine the world of facts in a credible way. ${ }^{48}$ Geertz quotes a Swiss anthropologist who refers to adjudication as a

45. Dronenburg v. Zech, 741 F.2d 1388, 1397 (D.C. Cir. 1984). Justice Bork's majority opinion stated that, unlike the right to privacy asserted by petitioner, the Constitution creates "specific rights" that protect, among others, "ethnic . . . minorities." Id.

46. But see Strauder v. West Virginia, 100 U.S. 303 (1880). The Supreme Court adopted the view early, and without discussion, that white ethnic groups are entitled to fourteenth amendment protection akin to the protection for blacks. Id. I thus do not mean to suggest that finding ethnic discrimination within the purview of the equal protection clause is historically implausible. There had been, prior to the late 1860 s, significant public debate and agitation with respect to issues of ethnic discrimination.

47. C. GeERTZ, Local KNowledge: Further EsSays IN INTERPRETIVE ANTHRopolocy 171-73 (1983).

48. See id. at 173 . 
"back and forth movement" between fact and precept. 49 Turning our attention continually from one set of inputs to the other, we seek interpretations, each of which reinforces the credibility of the other.

To offer an obvious example, I would observe that many people support Roe $v$. Wade ${ }^{50}$ not because the decision resonates in any particular constitutional language, but because a contrary result would "interpret" the fetus as a rights-holding entity whose interests could overcome a conscious person's right to decide whether to bear a child-from their point of view, an incredible description of reality. ${ }^{51}$ Conversely, many people oppose Roe $v$. Wade ${ }^{52}$ not because of any asserted implausibility of Roe as a constitutional interpretation, but because, from their point of view, Roe would have them "interpret" fetuses as something other than human beings-a position they likewise find incredible.

If I am correct, then one reason why controversial moral philosophy plays so strong a role in the interpretation of fourteenth amendment rights is that the world of reality to which the fourteenth amendment applies is one of deep, universal experience and concern. Our observation of political and legal debate in this society teaches us that the choice among different plausible constructs of the fourteenth amendment's language will play a conspicuous role in the prevailing social understanding of such "facts" as, say, whether individual choice or discrimination has yielded lesser average incomes for blacks and women than for whites or for men. It is inevitable, therefore, that norm-bound interpretations of extratextual reality will be given a predominant role in the process of understanding the fourteenth amendment's language. Given what is perceived to be at stake, we cannot realistically expect our legal system to treat the fourteenth amendment as a bounded set of norms neatly separable from the facts to which they pertain.

\section{Conventionalism and the Constitutional Place of Administrative Agencies}

For all the foregoing reasons, controversial moral or political philosophy will inevitably play a central role in the legal community's interpretation of the fourteenth amendment and other constitu-

49. Id. at 174 .

50. 410 U.S. 113 (1973).

51. Petchesky, Introduction to Amicus Brief: Richard Thornburgh v. College of Obstetricians and Gynecologists, 9 Women's RTs. L. REP. 3, 6 (1986) (criticizing "fetus-centered" orientation of popular debate concerning abortion).

52. 410 U.S. 113 (1973). 
tional provisions that are opaque or strongly relevant to critical human rights issues. Certain characteristics of the fourteenth amendment text foreordain this result, thus differentiating that text from the Constitution's opening articles. Articles I and II, unlike the fourteenth amendment, establish universally recognized institutions. ${ }^{53}$ The words of these articles almost always have well-known ordinary meanings, whose applicability often follows conventional understanding quite readily. To the extent normative theory is needed to apply the words, it may be sufficient for such application to recur to normative theories about the operation of government that are conventionally well understood and are not presently at issue in our society. As a result, the "plain" meaning of these constitutional words, amplified where necessary by overt reference to conventionally understood governmental norms, frequently leads to plausible resolutions to a variety of administrative law questions. Moreover, I believe there is frequently no persuasive reason to disregard those conclusions.

\section{A. A Conventionalist Approach to Articles I and II}

In this portion of the essay, I will attempt to elaborate a conventionalist approach to interpreting articles I and II that rests on what I believe to be the common understandings of the words of these articles. I will later apply it to help identify three categories of cases: (a) cases where the method yields "easy," wholly plausible answers; (b) cases where the method seems to yield no determinate answer; and (c) cases where the method yields "easy" answers that are nonetheless troubling. If I am correct that each of these categories exists, it becomes necessary then to consider the implications of this method, and of its incomplete utility, for constitutional interpretation generally.

It was my opening hypothesis in this essay that, in separation of powers and federalism issues, we are returning to a reading of the Constitution's structural and operational provisions that most obviously reflects the conventional meaning of the document's language and its most conventionally understood implications. To make that claim plausible, it is necessary to outline a believable conventionalist account of how articles I and II may be read. This method is not formalistic in the strict sense of purporting to rely on logically necessary deductions from authoritative major premises, but perhaps no constitutional commentator today is truly formalistic in this

53. See U.S. CoNST. art. I (establishing powers and limitations of legislative branch); id. art. II (establishing powers and limitations of executive branch). 
sense. The conventionalist method is formalistic in a sense used by many constitutionalists (typically in an uncomplimentary way) in that it asserts that fairly determinate answers to legal disputes may be reached by reliance on a fairly defined set of materials. ${ }^{54}$ It denies, in other words, that all issues of meaning and of precept are fairly contestable, given certain premises that are not at issue in our society about the text and about the government.

The conventionalist method is explicitly antiformalist, however, because it overtly depends on antecedent normative premises to guide textual interpretation. ${ }^{55}$ These are normative premises not only about how texts should be treated ${ }^{56}$ (although these exist as well), but explicitly about how we want the world of government to behave. What distinguishes the conventionalist method from other possible approaches to interpretation is thus not any denial of the priority of normative commitment in reaching textual understanding. Rather, it is my hypothesis that much textual understanding vis-á-vis modern government administration is possible if we rely on a few normative premises that are wholly uncontroversial in society.

Some uncontroversial premises are so widely held as to appear wholly conventional and superficially value-free: for example, the convention that the word "President" in all its appearances refers to the same person. It is hardly necessary even to remind ourselves of such premises. To make my hypothesis clear, however, it is necessary to set forth three explicit premises that pertain either to the

54. See Tushnet, Anti-Formalism in Recent Constitutional Theory, 83 MICH. L. REv. 1502, 1506 (1985) (stating that formalist criteria "must have relatively well-defined cores about which there can be no question"). Professor Mark Kelman of Stanford once remarked in conversation that one rarely hears the word "formalist" these days without the label "arid" attached to it.

55. I believe that interpretation is impossible without prior normative premises. Whether or not this is universally true, it is clearly so with respect to articles I and II of the Constitution. In our April 4 discussion, Professor Diver alluded to the dilemma that best illustrates the point. Article II imposes an obligation on the President to "take Care that the Laws be faithfully executed." U.S. ConST. art. II, § 3. "Laws," as ordinarily understood, could refer either to congressional enactments or to all federal law, including the Constitution itself. If "laws" includes only congressional enactments, then the President's domestic powers vis-á-vis Congress are clearly of much lesser magnitude than if the latter view is adopted. Without some preconception of what the interbranch relationship should be, the text cannot be interpreted. The only alternative is to have a normative preconception that the historic intention of the document ought to control, and a plausible view of what the historic intention is. See generally Fuller, Positivism and Fidelity to Law-A Reply to Professor Hart, 71 Harv. L. REv. 630, 661-69 (1958) (arguing that legal rules cannot be applied without conception of their underlying purposes).

56. Some assumptions about how texts should be treated may be so devoid of any moral weight that these assumptions should be called "conventional," rather than "normative." Some conventions, however, may be so rooted in a normative vision about how communication can best take place that $I$ am not sure a bright line between the two is possible. In any event, this debate is outside the scope of my discussion. 
appropriate way of reading a prescriptive text or to our expectations as to the proper working of our government:

Premise One. Among the branches of the federal government, Congress should play the primary role in domestic policymaking.

Premise Two. Among the branches of the federal government, the President plays the primary and a significant role in implementing the substance of such policies as are enacted by Congress.

Premise Three. Respect for any prescriptive document's intended purposes requires that provisions of potentially broad applicability should not be read to abrogate provisions of potentially narrower applicability. ${ }^{57}$

Assuming these premises, it is possible to adhere to the following method in answering a great number of questions concerning government administration. I almost hesitate to call it a "method" because I believe I am doing no more than making explicit the processes we pursue, perhaps unconsciously, whenever we purport to be reading a text straightforwardly. In any event, the steps are as follows:

1. Once a constitutional question is posed, determine the constitutional language which, as conventionally understood, is plausibly relevant to the resolution of that question.

2. Considering the conventional meaning of the identified language, determine whether it is possible to answer the question posed. If only one answer is plausible, the question is presumptively resolved.

3. If more than one answer is plausible, determine, as our antecedent premises above are conventionally understood, whether one answer is the most likely to make possible the realization of all three premises. If so, the question is thus presumptively resolved.

4. Once the issue is presumptively resolved, consider whether the presumptive answer requires an incredible understanding of the "extratextual reality" to which it applies. If not, the presumptive resolution is "the answer."

I do not claim that this approach will answer all important questions, but it does answer a surprising number. It will yield answers, any attempted linguistic contradiction of which will ring false to any lawyer who has studied modern United States administrative law. ${ }^{88}$

57. This is a variant of the principle that textual integrity is an important ingredient of sound interpretation. See Dworkin, Law as Interpretation, in The Politics Of INTERPRETATION 249 (W. Mitchell ed. 1983). As Dworkin notes, "An interpretation cannot make a work of art more distinguished if it makes a large part of the text irrelevant, or much of the incident accidental, or a great part of the trope or style unintegrated and answering only to independent standards of fine writing." Id. at 254.

58. A recurring problem for conventionalists in interpretation is the identification of the 
Before considering issues the method cannot resolve, I would like to demonstrate the plausibility of the method. I will then discuss reasons for its incompleteness.

\section{B. Easy Cases}

I believe the steps outlined above provide ready answers to a series of questions that administrative lawyers often consider controversial. The first issue is the legality of the legislative veto. Article I, section 7 states that not only "every bill,"59 but also "every Order, Resolution, or Vote to which the Concurrence of the Senate and House of Representatives may be necessary . . . shall be presented to the President of the United States" for approval or disapproval.60 It is difficult to see how two-house vetoes, not presented to the President, can pass muster under this language. ${ }^{61}$ To permit two-house vetoes under the necessary and proper clause, in light of this language, would violate our third premise above. ${ }^{62}$ If that is true, then the question in INS v. Chadha ${ }^{63}$ was essentially, is there any reason to think that one-house vetoes are more permissible than two-house vetoes? That is, should a "vote" of one house identical in form and purpose to an impermissible vote of two houses be excluded from the purview of the term "vote?" No matter what purpose is ascribed to article I, section 7, I cannot imagine an affirmative answer to that

community whose practice and understanding is relevant to the determination of meaning. Professors Fiss and Burton argue that the "legal community" is the relevant and authoritative community. Fiss, Objectivity and Interpretation, 24 STAN. L. REv. 739, 745-50 (1982); S. BurTON, supra note 23, at 125-43. This is problematic, however. Because the Constitution establishes not only a legal but also a political community, all persons subject to the Constitution seemingly have some claim to participate in its interpretation. See Carter, supra note 17, at 835-40; Brest, Interpretation and Interest, 34 STAN. L. REv. 765, 771 (1982). Although I generally regard this theoretical problem as a serious one, it seems of little consequence here because I do not perceive that lawyers understand "Congress" or a "resolution," or "nominate," for example, any differently from the understandings of any English-speaking American with a modest degree of civic education.

59. U.S. Const. art. I, § 7, cl. 2.

60. Id. at cl. 3. In INS v. Chadha, 462 U.S 919 (1983), the Supreme Court held that the one-house veto, retained in congressional legislation, infringed upon the executive branch's authority under this article I language. Id. at 955-59.

61. Following its decision on one-house vetoes in Chadha, the Supreme Court summarily held two-house vetoes unconstitutional. Process Gas Consumers Group v. Consumers Energy Council of Am., 463 U.S. 1216 (1983), aff'g, 673 F.2d 425 (D.C. Cir. 1982).

62. Buckley v. Valeo, 424 U.S. 1,135 (1976). The Court stated that Congress could not use one part of the Constitution to invalidate the provisions of another. The Court said:

[C]ongress could not, merely because it concluded that such a measure was 'necessary and proper' to the discharge of its substantive legislative authority, pass a bill of attainder or ex post facto law contrary to the provisions contained in section 9 of Article I. No more may it vest in itself, or in its officers, the authority to appoint officers of the United States when the appointments clause by clear implication prohibits it Id. from doing so.

63. 462 U.S. 919 (1983). 
question. Certainly, the normative premises animating our understanding compel none.

Second, consider the issue of appointments. Article II, section 2 provides four modes for the appointment of officers of the United States. ${ }^{64}$ In originally structuring the Federal Election Commission, Congress did not constrain itself to these four modes. ${ }^{65}$ The consequent assessment of the legality of the Federal Election Commission appointments was complicated by the fact that the text is ambiguous as to whether these four modes of appointment shall be exclusive. One may ask, however, whether it is possible to ascribe sensibly any purpose to article II, section 2 that would render these provisions non-exclusive. Again, I cannot; I think the attempt to persuade someone that a Federal Election Commissioner is not an "officer of the United States" under article II would evoke a sense of game playing in any reader attentive to text alone. Thus, Buckley $v$. Valeo ${ }^{66}$ seems to me an easy case on textualist grounds.

Next, consider the constitutionality of requiring the President to show "cause" before removing an agency head from office. Again, the text seems to yield a natural answer. Congress has the power to make all laws necessary and proper for carrying into execution not only its own powers, but all other powers vested by the Constitution "in the Government of the United States, or in any Department or Officer thereof." 67 In connection with removals, the only plausibly relevant textual limitation on this power is that the President is vested with the obligation to take care that the laws be faithfully executed. 68 But, so long as he can discharge any officer who is not faithfully executing the laws-that is, discharge "for cause"-it seems that his constitutional obligation remains unimpaired. Again, I perceive no interpretive difficulty. ${ }^{69}$

64. U.S. ConsT. art. II, $\S 2, \mathrm{cl}$. 2. The President nominates and, with senatorial advice and consent, appoints certain designated officers and all other officers, except that Congress may vest the power to appoint "inferior" officers in "the President alone, in the Courts of Law, or in the Heads of Departments." Id.

65. Under the 1974 amendments to the Federal Election Campaign Act, the Commission included eight members. Federal Election Campaign Act Amendments of 1974, Pub. L. No. 93-443, \& 310, 88 Stat. 1263, 1280-88. These included: (a) two appointed by the Speaker of the House upon the recommendations of the majority and minority leaders, (b) two appointed by the President pro tempore of the Senate, upon the recommendations of the majority and minority leaders, (c) two appointed by the President, and (d) the Secretary of the Senate and the Clerk of the House, serving ex officio. A majority of both Houses was required to confirm each of the six voting appointees. Id. at 1280-81.

66. 424 U.S. 1 (1976). In Buckley, the Court held that the appointment of the Federal Election Commission violated article II. Id. at 143.

67. U.S. Const. art. I, § 8, cl. 18.

68. U.S. ConsT. art. II, $\$ 3$.

69. My analysis is predicated on the assumption that no significant domestic authority beyond the specific clauses of article II is plausibly delegated by the opening clause of that 
My final problem is the scope of presidential authority to guide administrative agencies in the exercise of their statutory discretion. I have argued elsewhere that, where Congress places no statutory limits on the President's power, a straightforward reading of the faithful execution clause, buttressed by the vesting of executive power in a single individual, supports the assertion that the President has implicit power to oversee agency discretion for the purpose of implementing Congress' overall program most effectively. ${ }^{70}$ It seems to me, however, that an equally straightforward reading of the "necessary and proper clause" strongly supports the assertion that Congress has implicit power to prevent the President from doing so, if Congress so desires. Imagine a rulemaking authorization containing the following section:

In issuing rules under this act, the administrator shall rely entirely on the statutorily specified criteria and shall not base his or her decisions on the anticipated impact of those decisions on regulatory initiatives authorized by other statutes. The administrator's decisions may be based on data or analysis supplied by the President of the United States, but (a) such data and analysis shall be given only such weight as the administrator deems appropriate in light of the statutorily specified decisional criteria, and (b) such data and analysis, if relied upon by the administrator, shall appear in the rulemaking docket.

I perceive nothing in the Constitution that would render such a section impermissible. ${ }^{71}$ Upholding such a statute would not under-

article, which vests "the executive power" in the President. U.S. CoNST. art. II, § 1. Neither Alexander Hamilton, in his contemporaneous review of article II, THE FEDERALIST Nos. 67-77, nor the Supreme Court, in its subsequent review, infers any such power. But of. Myers v. United States, 272 U.S. 52, 164 (1926) (dicta locating presidential removal power in vesting clause). Locating significant powers in the opening clause would violate the rule against reading provisions of potentially broad applicability so as to abdicate provisions of narrower applicability.

70. Shane, Presidential Regulatory Oversight and the Separation of Powers: The Legality of Executuve Order No. 12,291, 23 ARIz. L. REv. 1235 (1981). In one respect, I believe Professor McGarity misapprehends the views expressed in my earlier article. He writes: "Professor Shane suggests that this interstitial power [of regulatory oversight] will not be abused by the President's staff in the Office of Management and Budget ...." McGarity, supra note 14, at 482. What I actually said on this point was that the limited institutional capabilities of OMB gave "reason to believe OMB will stick to a more general policing role, pressing consultation and analysis on the President's primary concern with cost-effectiveness," rather than trying to reanalyze the detailed substance of all agency decisions de novo. Shane, 23 ArIz. L. REv. at $1250 \mathrm{n} .81$. I concluded that presidential "policy oversight need not compromise the value of specialized agency expertise" "if the system works well." Id. (emphasis added). Whether OMB would exercise its management discretion properly as to any particular regulation is a topic I expressly reserved from my discussion. Id. at 1237. As Professor McGarity observes, we might be in agreement in our assessment of OMB's actual practice to date. McGarity, supra note 14 , at 482 n. 197 .

71. At our April 4 session, Professor Oliver Houck of Tulane posed the question of whether Congress could prohibit the President, in any particular rulemaking, from communi- 
mine any of the antecedent normative premises discussed above.

If the foregoing analyses are sound, then conventionalist interpretation does yield plausible answers to some questions that are commonly considered problematic when more controversial normative theories are explicitly relied upon to guide constitutional interpretation. Of course, the fact that answers yielded by conventionalist interpretation are plausible does not mean that they are likely to lead to fair, effective, accountable government operation. Yet, with respect to each of the cases above, I have found no compelling evidence that the conventionalist answers are less likely to lead to fair, effective, accountable government than the answers that might be yielded by more controversial and elaborate normative interpretive approaches. If I am correct, then conventionalism yields answers to some constitutional questions that are not only plausible, but as useful as any alternative answers for sound governmental design. This is all the more acceptable because the precepts I derive from the Constitution by means of a conventionalist approach leave substantial discretion over institutional design to Congress and the President, to whom the subtler arguments about fairness, effectiveness, and accountability may more profitably be addressed.

\section{The Incompleteness of Conventionalist Textualism}

Even if the foregoing analysis is correct, it is obvious that the textualist method does not plausibly answer all constitutional questions concerning administrative structure and operation, much less all constitutional questions generally. The inadequacies of the textualist method may be a result of the reasons explained earlier for the role of controversial normative theory in interpreting the fourteenth amendment: textual opaqueness or the predominant significance of interpreting extratextual reality. In some cases, moreover, the Constitution may not appear to contain any language specially relevant to the problem posed either because no provision appears relevant or, more likely, because so many provisions are potentially relevant as to preclude any textualist reading from appearing authoritative. ${ }^{72}$

cating his views in any form to the agency involved. Houck, President $X$ and the New (Approved) Decisionmaking, 36 AM. U.L. REv. 535, 550-53 (1987). Apart from the possible first amendment problems such a broad prohibition would raise, I would reject this possibility under the necessary and proper clause because it would violate my second uncontroversial normative premise that the President plays the primary and a significant role in implementing the substance of such policies as are enacted by Congress.

72. An instance of such textual unhelpfulness is the Constitution's seeming silence on the foundational issue whether federal courts may treat unconstitutional federal statutes as having no legal effect. The structure of Chief Justice Marshall's argument in Marbury v. Madison, 5 U.S. (1 Cranch) 137, 171-80 (1803), reflects this difficulty. 
There are two additional reasons for the incompleteness of textualism, however, that apply even when conventionally meaningful constitutional language is identifiably relevant to a posed constitutional question. On the one hand, "plain reading" will not yield an acceptable answer to a posed legal question when the uncontroversial antecedent premises are insufficient to determine which potential textual meaning is best. That is, in a particular case, the normative premises could consistently support or contradict any number of meanings equally well. These are cases of indeterminacy. Some such cases are only falsely indeterminate; a textualist answer may become possible once we add to our catalogue of antecedent normative premises an additional uncontroversial premise that had not yet come to mind. In some cases, however, in order to resolve an indeterminacy, we must apply normative premises that are not so widely shared as to be considered uncontroversial.

In my view, an example of a question unresolvable through textualism alone is the existence vel non of executive privilege. ${ }^{73}$ Under the textualist method above, consider whether the President, absent congressional authorization, is constitutionally empowered to keep secret from the public any communications or documents relating to the implementation of domestic policy. No such power appears in article II. By contrast, Congress has express power to keep its journals secret under article I. ${ }^{74}$ Further, the existence of congressional power to make laws necessary and proper for carrying into effect executive, as well as legislative, power buttresses the apparent inference that any power to keep executive secrets depends on Congress. ${ }^{75}$ Such an inference would not appear to undermine any of the three antecedent normative premises articulated above.

On the other hand, I believe a conventionalist reading of a powerconferring provision of any document presumes that the power conferred includes all authority essential to the implementation of the named power. Therefore, a conventionalist reading would support executive privilege if the President's inability to prevent the public outflow of a deliberative document would cripple his ability to perform a named power. ${ }^{76}$ Such a reading also would not undermine

73. See generally United States v. Nixon, 418 U.S. 683, 703-13 (1973) (discussing merits of executive privilege claim in criminal proceeding context).

74. U.S. CoNST. art. I, \& 5, cl. 3.

75. Cf. Van Alstyne, The Role of Congress in Determining Incidental Powers of the President and of the Federal Courts: A Comment on the Horizontal Effect of the Sweeping Clause, 40 LAw \& CoNTEMP. Pross. 102, 128 (1976) (describing congressional role to authorize executive privilege through necessary and proper clause).

76. It might be said that I have not sketched any genuine dispute as to interpretation, but rather pointed out the difficulty of applying the interpreted text to a fact-based claim of neces- 
any of my uncontroversial antecedent premises.

It might be argued that the pro-privilege reading is clearly preferable once the essential necessity of executive privilege in implementing specific presidential powers is demonstrated. I cannot imagine, however, any noncontroversial way of demonstrating that any particular assertion of executive privilege is so necessary. Further, given the controversy that arises when such a demonstration is proffered, a reader of the Constitution is likely to find this conventionalist reading no less controversial than other interpretive methodologies directed at the text, such as relying on historical understanding, that might yield different answers. Thus, the conventionalist approach I have outlined cannot alone answer the legal question posed. The indeterminacy is all the more conspicuous when questions arise as to when such a privilege may be exercised and against whom. ${ }^{77}$

My conventionalist method also will fail where relevant, conventionally meaningful language exists, but the conventional interpretation (a) undermines an uncontroversial normative premise not made part of the interpretive scheme, (b) the undermined premise is indisputably of key importance to the community's perception of a proper answer to the question posed, and (c) the relevant language cannot be conventionally read to produce the answer indicated by the uncontroversial "extra" premise. In other words, my method will fail where the presumptive answers yielded by the text require an incredible interpretation or reinterpretation of the extratextual reality to which the text refers.

I find it difficult, however, to identify any such case involving a question of administrative agency design. An example from the rights-defining "side" of the Constitution is, however, familiar. Consider whether the federal government has any obligation to guarantee persons equal protection. Surely the absence of an equal

sity. Professor Van Alstyne, a narrow construer of executive privilege unsanctioned by Congress, would apparently not object to a nonstatutory assertion of executive privilege based on a need to avoid "crippling" the President's ability to perform an assigned function. Id. It seems to me, however, that, when text cannot be uncontroversially applied, its interpretation must likewise be considered controversial. Thus, I do not understand Professor Fiss' statement that controversies, for example, over the historical data relevant to understanding the equal protection clause pose little threat to the legitimacy of the disciplining rules of interpretation, as they pose only issues of application. Fiss, supra note 58, at 747. It seems to me that, if the debates over interpretation are to have any importance, whether rules of interpretation are, indeed, to be considered "disciplining" or "legitimate" must depend wholly on how the interpreted text is to be applied.

77. See Shane, Legal Disagreement and Negotiations in a Government of Laws: The Case of Executive Privilege Claims Against Congress, 71 MinN. L. REv. (1987) (forthcoming) (describing three distinctive understandings of executive privilege law among the three branches of the federal government). 
protection clause in the fifth amendment and its presence in the fourteenth implies a negative answer. Yet, in Bolling $v$. Sharpe, ${ }^{78}$ the court held differently, reaching the only normatively acceptable result given the implausibility of allowing the nation's capital to be the only permissible situs for racially segregated schools.

In sum, my conventionalist approach answers some important questions, but quite clearly not all of them. It is satisfactory only in those cases where identifiably relevant language exists, that language is susceptible to interpretation through conventional reading, uncontroversial normative premises exist to help decide among plausible alternative readings of the relevant text, and the resulting textual answer does not require us to reinterpret extratextual reality in an incredible way.

\section{The Nondelegation Doctrine}

There is, however, an additional level of interpretive difficulty to be confronted, and that is the uncertainty that may arise in a particular case as to the existence of those conditions that make a textualist reading of the Constitution possible. This is the case with the nondelegation doctrine. The subject merits discussion both because of the concerns raised in the presentations by Professors Lowi and Stewart, and because the nature of the interpretive anxiety that surrounds delegation may shed light on the utility of my version of conventionalism as an interpretive strategy.

Although the literature bemoaning the desuetude of the federal nondelegation doctrine is considerable, a conventional reading of the text does not necessarily suggest any broad nondelegation doctrine at all. The usual reading of the text that supports the existence of a nondelegation doctrine runs as follows: The Constitution vests "legislative power" in Congress. "Legislative power" is, in general, the power to make rules with the force and effect of law, and, for Congress, the power to "regulate" for the purposes enumerated most exhaustively in article $I$, section $8 .{ }^{79}$ Therefore, the making of binding rules, in general, or the issuance of "regulations" for article $\mathrm{I}$, section 8 purposes is "legislative power" vested in Congress that cannot be abdicated to any other branch. No other branch possesses "legislative power."

A yet more plausible plain reading, however, is possible. This reading begins with the observation that article I does not vest ex-

78. 347 U.S. 497 (1954) (holding that District of Columbia must desegregate despite absence of any explicit guarantee of equal protection from federal action).

79. See U.S. ConST. art. I, \& 8. 
clusively in Congress an unspecified category of "legislative powers" with extra-constitutional definition, but refers instead to "[a]ll legislative powers herein granted." One might conclude from this that rulemaking performed by administrative agencies is not a "legislative power" in the constitutional sense for the simple reason that such rulemaking is not a legislative power to which the Constitution refers. Although Congress could perform rulemaking under one of its express powers, it has determined, under the authority granted by the necessary and proper clause, to remove rulemaking from the category of "legislative powers" granted in the Constitution and to render it an administrative task. Such a reading does not abrogate the vesting of regulatory power in Congress; it merely recognizes that Congress may "regulate" not only by issuing rules, but also by authorizing others to issue rules, subject to congressional revocation of rulemaking authority. Any such authorization renders rulemaking nonlegislative, for constitutional purposes, despite what Professor Bruff has elsewhere labeled the "functional similarity [of rulemaking] to legislation." 80 This reading seems not only as respectful to my antecedent normative premises as the anti-delegation reading, but more so because the nondelegation doctrine prohibits Congress from adopting a range of plausible domestic policy choices, namely, choices to delegate broadly. This limitation on Congress conflicts with my premise of congressional primacy in domestic policymaking.

The strength of one's belief in the presumptive legitimacy of congressional policymaking may lead one to regard the delegation question as an "easy case" in favor of delegability on conventional reading grounds. There is nevertheless a rub. The primacy of Congress in domestic policymaking was, indeed, one of the assertedly uncontroversial premises articulated above. But that statement of my premise leaves unresolved what, in this context, becomes a key question: should my premise be understood to refer to the scope of Congress' authority, that is, to its potential policymaking role, or to the range of policies Congress has adopted, that is, to its actual policymaking role? If the former, then my proffered view of the nondelegation doctrine is truly untroubling. On the other hand, the fact that broad delegation may reduce Congress' actual (as opposed to its potential) policymaking role may prompt some "plain readers" to reject broad delegation under my first "uncontroversial" premise. The uncertainty as to the meaning of this premise (and, I

80. Bruff, Legislative Formality, Administrative Rationality, 63 TEx. L. REv. 207, 207 (1984). 
believe, the impossibility of resolving it noncontroversially) robs it of any value in deciding between the plausible conventional readings of the Constitution with respect to congressional delegation of legislative power. Thus, we are faced with textual indeterminacy.

Indeed, the uncertainty here runs deeper. A knowledgeable observer, such as Professor Lowi, might even be persuaded that the prodelegation textual reading is correct under a dictionary-type understanding (bolstered by my uncontroversial interpretive premises). He would regard that reading, however, as a "wrong answer" to the issue of delegability because it would require him to accept a version of political reality which he regards as incredible. ${ }^{81}$ Given Professor Lowi's normative understanding of how a liberal democracy is to be run, he could not accept a prodelegation textual reading. Recognizing these likely alternative viewpoints, I cannot perceive a noncontroversial way of using my premises concerning government behavior to choose among competing "plain readings" of the text. Even if we could choose among such readings, I predict that a conventionalist answer would nonetheless fail because, for many, it may require an unacceptable view of extratextual reality.

Thus it is on the question of delegability that genuine constitutional anxiety exists-anxiety that challenges not only independent agencies, but much of modern government administration, no matter who the administrator(s) may be. It is a question that cannot be contemplated, much less answered without reference to controversial normative premises. ${ }^{82}$

\section{Should Courts Ever Be Textualist?}

I have outlined conditions under which a particular conventional-

81. Lowi, Two Roads to Serfdom: Liberalism, Conservatism and Administrative Power, 36 AM. U.L. REv. 295 (1987).

82. My own position is very different from Professor Lowi's on this issue. I do not dispute, of course, that the current world of checks and balances looks profoundly different from the framers' world of 1789 . Yet, I do not see that modern delegations of power from Congress to the bureaucracy have undermined the old-fashioned checks and balances. No systemic violations of popular sentiment, of due process, or of the substantive rule of law have been identified. This leads me to the conclusion that the system in operation is both checked and balanced.

Although agencies perform imperfectly, sometimes even corruptly, these failings do not seem related to the breadth of agency delegation. Indeed, as Professor Mashaw has recently argued, it is possible to make a strong public welfare case for broad delegation. Mashaw, ProDelegation: Why Administrators Should Make Political Decisions, 1 YALE J. ECON. \& ORg. L., 81, 9195 (1985). The specter of tyranny from this source seems truly remote. Yet, while disagreeing with Professor Lowi, I see no textual way of adjudicating between our differing positions. Textualism seems to me to answer many important questions of administrative structure and design; yet, it does not answer the most central issue-the proper scope of administration per se. 
ist strategy of textual interpretation represents a useful technique for constitutional interpretation and conditions under which it does not. I have noted that my version of textualism leaves unanswered the question, central to virtually all modern administrative law, of delegability. Given these limitations on the general applicability of my method of constitutional interpretation, the question remains whether courts (or commentators) should ever apply a conventionalist strategy of textual interpretation even in those cases where textualism is plausible.

This dilemma may be best understood in light of a concrete case. Imagine that the constitutionality of a two-house legislative veto is being litigated (pre-Chadha). As explained above, conventional reading unambiguously points to the unconstitutionality of the veto under identifiably relevant language. Its conventional meaning, amplified barely by reference to uncontroversial antecedent premises, is fairly certain. The presumptive resolution the language dictates does not require an interpretation of extratextual reality-here, the reality of government administration-that defies credibility.

Yet, a proponent of the veto may attempt to introduce controversy into the proceedings through either of two additional arguments. A proponent might concede the correctness and weightiness of the textualist's answer, but argue that reading the text according to its conventional meaning is less preferable than an alternative interpretive strategy. Alternatively, the veto proponent might contend that the criteria for finding an answer under my method are not sufficient to assure us that the answer is even presumptively correct.

The first strategy questions not the logic of my method, but its authority as an interpretive technique. It suggests that another interpretive strategy is normatively better. The principal alternative to a conventional meaning approach is likely to be a historical approach to interpretation. Its normative defense is that it is more likely to give effect to the design of the document's originators. Thus, hypothetically, an advocate might point to an express (and prescient) discussion of legislative vetoes at the 1787 Convention which indicates that, although the drafters drafted badly, they intended to permit legislative vetoes. Here, a conventional reading of the text would yield the "wrong answer" not because of the insufficiency of its premises, but because history dictates a reading of the text that is more privileged than a reading based on the text's conventional meaning.

In general, however, I believe that arguments derived from conventional meaning are stronger than arguments derived from his- 
tory, keeping in mind, however, that I am proposing textualist answers only if they do not require incredible interpretations of extratextual reality. Arguments derived from conventional textual meaning have two main advantages, accessibility and certainty. For example, with alternative readings of the Constitution-one that is accessible to all readers and one that is accessible only to the historically-educated-I believe that a democratic government will properly and naturally incline toward the former, even if a coherent historically based answer is imaginable. Fundamental law that is readily understood by those who are subject to it is of great value in a democratic society. Further, in those cases where conventional understanding establishes a meaning for constitutional language beyond fair controversy, it seems improbable, at best, that historical inquiry can coherently establish a competing interpretation that we can accept with equal confidence. ${ }^{83}$ Thus, when a conventionalmeaning approach yields a plausible, determinate answer to a constitutional question, an advocate is unlikely to displace that answer successfully by resorting to a wholly different interpretive approach.

The second method of establishing controversy is, of course, by challenging the strategy of textualism itself. An advocate might accept that conventionalism, as I have outlined it, would yield an answer, but argue that the answer is unworthy of weight. For example, an advocate might concede that the unconstitutionality of the veto would not yield an incredible theory of government and is, therefore, an acceptable result for the "plain reader." Such an advocate might argue, however, that the mere plausibility that legislative vetoes are unnecessary for sound government is not a strong enough reason to accept the conventional textualist reading as correct. An advocate might even urge, albeit controversially, that the Court weigh an additional argument in deciding how to read the Constitution. This argument would assert that responsible government requires that important policy decisions be readily subjected to the oversight of elected officials, not just bureaucrats. If that argument is accepted, our advocate would say that the conventional textualist's answer is wrong because prohibiting two-house vetoes during the oversight process would interfere with the important goal of government accountability.

Our advocate would recognize, of course, that equating accountable government with congressional oversight as permitted by the legislative veto is a controversial conclusion. Such an advocate

83. See Brest, supra note 30 , at 234-37 (arguing that adjudications should treat text and original understanding "as persuasive but not authoritative"). 
might say, however, that issues of government design are so important that a court should adjudicate between competing theories of government operation in giving meaning to the relevant constitutional terms. In this view, it is not enough that uncontroversial premises of government yield a textual reading that is plausible. If a court is fairly persuaded that one governmental theory, although controversial, is better than another, it should feel free to read the constitutional text in a way that helps implement the better theory, even if the textual reading departs from popular, conventional definitions of the words involved.

Although I have great sympathy for such a stance, I would not agree with it in the case of a legislative veto. When faced with a question to which the Constitution, plainly read, yields a plausible answer, I see no reason to believe that reading the text "creatively" will produce results more likely to foster good government. The functional arguments for and against legislative vetoes are numerous and have been made strongly, but I perceive no way in which a court could have confidence in one set of arguments or the other sufficient to overcome the answer all but dictated by the text when plainly read. This, I believe, is what some commentators imply when they state that courts are formalistic in cases such as these because there is no intellectually supportable alternative. ${ }^{84}$

Nonetheless, many commentators, I believe, will be wary of a conventionalist approach that is as plain meaning-oriented or textbound as the one I have outlined. Two reasons would prompt their skepticism. The first is a fear that constitutional literalism is unresponsive to contemporary administrative reality, especially the breadth of congressional delegations of administrative power. Justice White urged in Chadha, for example, that we should recognize the new world and, in effect, adjust our views of the text to accommodate broader constitutional norms of accountability in the real world of administrative discretion. ${ }^{85}$ The second reason for skepticism is that all of the Constitution is normative. Formalistic inter-

84. See generally Mashaw supra note 82 , at $91-95$. It is not as clear to me as it may be to Professor Mashaw, however, that formalism and nonjusticiability are the only appropriate judicial responses to separation of powers disputes. In some cases, where formalism fails, judicial forbearance (under the guise of nonjusticiability) might require a political solution to an interbranch problem. The political solution used to break the impasse may simply involve a greater cost to the working of government than would judicial imposition of a functionalist "rule." Cf. Bruff, supra note 13, at 504-05 (claiming that "use of [a functional] approach seems appropriate in some limited circumstances where the constitutional text is silent and judgments about the need for some constitutional protection depend more on common sense than on complex fact questions").

85. INS v. Chadha, 462 U.S. $919,984-89$ (1983) (White, J., dissenting). 
pretation of any sort may blind us to the constitutional value choices that administrative design truly implicates.

Let me first address the formalist's supposed blindness to constitutional value choice, for it is here that I find the difference between the Constitution's opening articles and the fourteenth amendment to be so telling. The organization of governmental structure and process does, of course, embody value choice, but unlike the value choices manifested in individual rights provisions, the value choices of articles I and II are embodied in relatively precise structural directives. This is not true with the fourteenth amendment. Thus, when the Supreme Court replaced Plessy v. Ferguson ${ }^{86}$ with Brown $v$. Board of Education, ${ }^{87}$ nothing in the Constitution had to be rewritten or ignored. There was no constitutionally erected institution to be sidestepped or supplanted.

Such is not the case with articles I and II. These articles describe conventionally understood structures and processes. They do so for normative purposes. To vindicate those purposes through new structures or different processes, however, would mean ignoring constitutional language with plainly understood conventional meaning while leaving intact governmental institutions that adhere to constitutionally described procedures that might eventually seem only eccentric. No case for making this leap has been persuasively made. If we are to leave intact the governmental machine that the Constitution describes, it seems the most functionalist of philosophies to follow the Constitution's operating instructions as well, at least until we truly believe that constitutional purposes require replacement of the machine itself.

As for ignoring modern reality, I do not perceive any change in government so profound that following functionally plausible, conventionally understandable readings of the operational provisions of the Constitution would pose the threat of anachronism. On the delegability issue, for example, I perceive no threat to any timehonored constitutional value by permitting Congress to extend rulemaking power to agencies, so long as such rulemaking power is practicably constrainable through ordinary judicial review. I likewise perceive both positive social value to broad delegation and positive political value in respecting Congress' presumptively valid value choice of this now commonplace mechanism for specifying economic and social regulation. Article I empowers Congress to make laws "necessary and proper" for carrying out its regulatory 
tasks. I would read that text, as did Chief Justice Marshall, to authorize comprehensively all laws appropriate in fact and otherwise constitutional for implementing Congress' functions. ${ }^{88}$

There is an additional value of textualism that is worthy of mention. If one believes, as I do, that plain meaning yields nothing as to some portions of the Constitution, then the plausibility of textualism vis-á-vis other constitutional questions necessitates an eclectic approach to the Constitution-part avowedly philosophical, part superficially literalist. To my mind, and, I take it, to Professor Sargentich's, ${ }^{89}$ this eclecticism is welcome because it captures an appropriate pluralism in our aspirations for good government. There are issues where we want most critically to be right. Rigorous public deliberation of contending visions of the public interest gives voice most effectively to that aspiration. Here, formalism has no role. There are, however, contexts-the details of government administration provide many of them-where we also want to be orderly, where express adherence to a well-understood formal rule of law gives voice to our aspirations for control and accountability as part of justice. It would be advantageous, in my view, if textualism in constitutional interpretation vis-á-vis administrative agencies passes the message to government officials that, sometimes, we just want them to do what they are told.

I do not mean by this to overstate the plausible scope of textualism as an interpretive strategy, or to dismiss as unimportant any of the sophisticated thinking on the norms of governmental structure and operation proffered by others. That kind of thinking is essential in the pursuit, however frustrating, of a government that behaves in the public interest. I do believe, however, that virtually all of this sophisticated thinking should be addressed to Congress with its expansive powers to design administrative agencies, or to the President with his implicit interstitial power to oversee agency administration. As for the constitutional questions, I agree with many, if not all, constitutional conclusions I have read in such comprehensive analyses as Professor Bruff's earlier article on presidential regulatory oversight ${ }^{90}$ or Professor Strauss' recent examination of independent agencies. ${ }^{91}$ My core suggestion is that the Constitu-

88. McCulloch v. Maryland, 17 U.S. (4 Wheat.) 316, 421 (1819).

89. Sargentich, The Delegation Debate and Competing Ideals of the Administrative Process, 36 AM. U.L. REv. 419, 441 (1987) (arguing the importance of recognizing that modern debates about administrative reform are "deeply balanced among competing ideals").

90. Bruff, Presidential Power and Administrative Rulemaking, 88 YALE L.J. 451 (1979) (exploring scope of presidential oversight within separation of powers framework).

91. Strauss, The Place of Agencies in Government: Separation of Powers and the Fourth Branch, 84 Colum. L. Rev. 573 (1984) (arguing that only Congress, President, and Supreme Court must 
tion provides a quicker route to the solution of many problems than does resort to broadly articulated normative theory. It is the Supreme Court, not the Constitution, that sometimes makes the constitutional route difficult to discern. 
